\title{
Windows of Faith
}

\author{
Gisela Webb, ed. Syracuse, New York: \\ Syracuse University Press, 2000. 295 pages.
}

Windows of Faith provides a space where Muslim women speak for themselves and challenge rigidly traditionalist voices that have often had hegemonic status in Islamic jurisprudential works regarding women. It is a volume that represents the voices of some of the most highly regarded Muslim women scholars and activists today. The book appears to cater to a primarily academic audience, and one that is familiar with the tradition of Islamic feminism.

In her introduction, Gisela Webb describes the overall approach of the contributors as challenging hegemonic discourse in many circles. It challenges: elements within the Muslim and the non-Muslim imagination that define Muslim women as mute victims; western feminist patriarchy toward Muslim women; and also the Muslim cultural patriarchy that appropriates the sources of Islamic law and praxis yet, in the view of (probably all of) these women, has abandoned the essential Divine egalitarian purposes. Windows of Faith is a refreshing read, especially due to today's urgent need to respond to the Qur'anic challenge: Do they not reflect?

In the first part (Qur'anic/Theological Foundations) Amina Wadud's piece "Alternative Qur'anic Interpretation and the Status of Muslim Women" explores neo-traditionalist and secular approaches toward alternative interpretation of the Qur'an regarding the status of women. It is interesting to examine her comment, "Being anti-western has become a basis for legitimacy in 'Islam' " against some of Maysam al-Faruqi's comments in her chapter, which seem to dichotomize "Islamicness" with westernness in the context of gender relations. In the second chapter "Muslim Women's Islamic Higher Learning as a Human Right," Nimat Barazangi seeks, through an analysis of qualitative research with Muslim women, to develop an "action plan for the Muslim woman" in the postmodern era, "to regain her identification with Islam." The need of the hour is to "reinstate woman as an educational agent, both at home and at the mosque one who herself will outline her priorities as a trustee entrusted with changing history toward social justice." Will we see women as well as men delivering khutaba and instituting policies in mosques and communities? Will we see women teachers as well as male principals 
and board members establishing curricular practice and school policy? In many of the mosques I am familiar with, this would appear to be a dream at present.

Part Two ("Law") is the largest section, with four chapters authored by Azizah al-Hibri, Maysam J. al-Faruqi, Asifa Quraishi and Aminah McCloud. Al-Hibri is opposed to western-imposed coercive change in Muslim societies, and insists on an indigenous Muslim women's movement. The Qur'an promotes women's status through affirmative action, and it should be the source of a women's movement in Muslim societies. Western women's neo-Orientalist attack on Islam has hurt the cause of Muslim women's rights.

Al-Hibri bases her argument for gender equality on the Tawhid principle. She shows that patriarchal worldviews and claims of male superiority are based on satanic logic and shirk. One cannot help but be amused when, with somewhat mischievous humor, al-Hibri concludes that in considering the legality under Islamic law of marriage with non-Muslim women, in the U.S. (where custody laws favor women), Muslim men "now deserve the protective attention of Muslim jurists."

Al-Faruqi's essay, "Women's Self-Identity in the Qur'an and Islamic Law" criticizes various apologetic and non-Muslim critiques of Islamic law. She starts by attacking "universalistic" approaches to gender issues which prioritize gender (over religion or anything else) as a source of identity. At times the quibbling over what comes first, religion or gender, seems rather trivial and unnecessary. To me, generally, all sources of identity appear to occur as simultaneous and essential to each other, rather than as inherently in conflict. It also seems limiting that, speaking on behalf of Muslims (which is a rather large and variegated category), Al-Faruqi places Islamic traditions in opposition to "universal" ones. Al-Faruqi should define what she means by universalism, "Muslim women" and "Muslims". There are many Muslims who would, on the basis of the Qur'an, appropriate universalism instead. She also begins with an oppositional stance against "the reformists" who stress some Qur'anic ideals over others, making their choices on the basis of western ideals "of course". These claims, it would appear, warrant some documentation and citations. Who are these reformists, and what Qur'anic ideals are "more western" than others? In another dichotomy, she sets "self-identified Muslims" against "token" Muslims (who, incidentally, "take feminism as their faith"). It is difficult to escape a sense of carelessness in the use of "feminism" as an ideology 
in conflict with Islam. Feminism has many meanings, and it does not necessitate abandonment of Islam. Intellectual honesty requires committed Muslim women also to acknowledge a debt to feminist theory and activism.

Quraishi's paper, "Her Honor" is a cutting edge study of the Pakistani legal system, which is riddled by glaring flaws due to the poor quality of Islamic learning and education among the religious as well as the state functionaries. She shows how the rape laws are constructed sloppily on the basis of zina (adultery) laws - despite the very different nature of those crimes - and how additional elements in those laws - such as restricting evidence to males - have served to destroy the egalitarian purposes of Islamic law. Unfortunately both the activists against those laws and the traditionalists in favor of them generally have little grounding in the Islamic legal tradition, and can hardly be said to speak the same language. Quraishi's work could be of great benefit to the Pakistani legal system, and the men and women it affects.

McCloud's article, "The Scholar and the Fatwa: Legal Issues Facing African American and Immigrant Muslim Communities in the United States", explores the legal impact of marriage- and divorce-related issues on Muslim women in the U.S.

Part Three is titled "Literature, Spirituality" - with the two words separated by a comma rather than 'and' which seems to place them - rather untidily - in the same category. In her chapter "Braiding the Stories: Women's Eloquence in the Early Islamic Era”, Mohja Kahf speaks of retrieving erased records of women's eloquence in the early Islamic era. She explores this under-studied subject through a study of balagha (eloquence), the tradition of the mujadila (woman who disputes), and gynocentric portrayals of manhood in the early Islamic era. The next article in this section, "Reading the Signs: Unfolding Truth and the Transformation of Authority" by Rabia Terri Harris is markedly different from the other contributions in its style of writing. She does indeed braid together a variety of different insights, in a pattern of metaphor and understatement.

In Part Four ("Activism") Simmons introduces as the subject of her essay a topic as large as "issues confronting contemporary Muslim women who question many of the traditions and views regarding the role of women both in Islam and in society in general." Her use of her personal experiences as a primary axis for her essay succeeds in binding the piece together only as a chatty autobiographical piece that belongs more to a 
collection of personal reflections than to a groundbreaking work in activism and scholarship. The connections between her reflections on the Beijing conference and her musings on various activist groups in Muslim societies are not fully developed. Also, her choice of geographical focus (Muslim societies) requires some explanation in a volume on North American activism.

Hassan's "Is Family Planning Permitted by Islam?" is concise, a series of steely arguments linked closely together. Hassan bases her article on the main arguments that the Islamic tradition is not monolithic, and that multiple sources of the Islamic tradition at times come into conflict with each other. She begins her argument on family planning with the contention that the Qur'an is a divine book of guidance and wisdom, the goal of which is not to provide laws in every single matter, but to enable human beings to realize their potential as God's vicegerents on earth. This statement is a direct challenge to the common neo-traditionalist claim that the Qur'an provides answers and laws to every matter of human concern. Arguably, a challenge such as Hasssan's should be substantiated with more than a stark, bare statement that almost seems to ignore the neo-traditionalist claim with patrician disdain.

The book includes two appendices: "Human Rights in the Qur'anic Perspective" by Riffat Hassan and "A Partial List of Organizations for Muslim Women's Rights, Advocacy, and Higher Islamic Education in the United States" by Kareema Altomare.

It is understandable, considering the pioneering nature of this project, occasionally to sense a looseness of connection among the various pieces in the volume. The book's categories appear to be generated more by necessity and the available contributions, than by a conceptual map. The contributions tend at times to be far too widely disparate in nature and style to hang together-contrast Hassan's terse rigor with Simmons' rather chatty, expansive autobiographical style. Indeed this may be a result of the rather disparate nature of contributions regarding activism and regarding scholarship. It may be a laudable goal and certainly an attempt toward holistic thought to combine the scholarly and the activist, the theoretical and the practical. Yet it is no mean challenge to smooth over the differences of approach between the two fields to bridge them together in a unified project.

As with any collected volume, Webb makes certain choices to define her selection, and Windows of Faith limits itself to prominent Muslim 
women of the academic elite within North America. One hopes to see similar volumes in the future that have a wider range of contributors, both geographically as well as academically. The typographical errors are too abundant for a volume of this quality and one would hope that a second edition would change that.

Windows of Faith is essential reading for anyone with an interest in Muslim women, North American Islam, contemporary Islamic studies, gender studies, modern religious perspectives on women, the development of religious law, and human rights issues in general. It will be particularly useful reading in university courses on religion in the West and Islamic feminism.

Shabana Mir Doctoral student Education Policy Studies Indiana University, Bloomington 